Royal Institution, chairman of the Norman Lockyer Observatory Corporation, and also president of the Egypt Exploration Society ; he is a Messel medallist of the Society of Chemical Industry, a past president of the French Society of Chemical Industry, and he has carried out noteworthy archæological excavations at Thebes, in Palestine, and in Brittany. The museum at St. Germain has been much enriched as a result of his excavations in Brittany. The Académie des Inscriptions, by its election of Sir Robert as a foreign associate member, has attracted to its service one whose knowledge in many fields can scarcely fail to promote its activities and influence.

\section{prof. A. F. Burstall}

Dr. Aubrey F. Burstall has been elected professor of engineering and dean of the faculty of engineering in the University of Melbourne, Australia. Dr. Burstall is a son of the late Prof. F. W. Burstall, who was professor of mechanical engineering in the University of Birmingham in 1896-1931. Dr. Burstall, who is thirty-four years of age, received his education at King Edward's School (New Street), Birmingham, at the University of Birmingham and at St. John's College, Cambridge. The results of his work on the combustion of various gaseous fuels in the high-speed internal combustion engine were published in a series of papers before the Institution of Automobile Engineers. Dr. Burstall joined in 1925 the staff of Synthetic Ammonia and Nitrates Ltd. at Billingham, which in 1928 became a constituent company of Imperial Chemical Industries Ltd. He held various positions of increasing responsibility on the engineering staff and in 1930 was appointed deputy chief engineer of the Billing. ham Factory. In 1933 he resigned his position to become technical adviser to the Aluminium Plant and Vessel Company of Wandsworth, London. The Fngineering School at the University of Melbourne, to which Dr. Burstall is going, is one of the largest in Australia, the students numbering nearly two hundred. During the last two years of the four year course the undergraduates specialize in either civil, mechanical, mining, electrical or metallurgical engineering before taking their degrees. Dr. Burstall succeeds Prof. Wilfrid Kernot, who is retiring in March at the end of the present academic year.

\section{Ernst von Bergmann}

ERNST VON BERGMANN, who was one of the most skilful surgeons and commanding personalities in Germany of the last century, was born at Riga on December 16, 1836. He received his medical education at Dorpat, Vienna and Berlin and qualified on November 13, 1860. He commenced his career as assistant in the Dorpat surgical clinic and afterwards served as a medical officer in the Prussian Army in the war with Austria in 1866 and in the FrancoPrussian war in 1870. He was elected professor of surgery at Dorpat in 1871. In 1877, when war broke out between Turkey and Russia, he became consulting surgeon to the Russian Army invading Rumania, and in the treatment of wounds carried out the antiseptic method just introduced by Lister. His activities as a military surgeon, however, were cut short by a severe attack of dysentery, and in 1878 he was appointed professor of surgery and senior surgeon to the Julius Hospital at Würzburg. He remained there until 1882, when he succeeded Langenbeck in the chair of surgery at Berlin. In 1887 he attended the Emperor Frederick in his last illness, when an unfortunate dispute as to the correct diagnosis and treatment arose between the German surgeon and Morell Mackenzie, the well-known London laryngologist and author of "Frederick the Noble".

VON BERGMANN is best known for his introduction of aseptic surgery, the principles and practice of which he described at the Tenth International Medical Congress held at Berlin in 1890 in conjunction with his assistant C. S. Schimmelbusch, whose work on the subject is a surgical classic. Von Bergmann also made a valuable contribution to the literature of military surgery by his works on injuries to the head and brain and gunshot wounds of the knee-joint. In association with Profs. von Bruns of Tübingen and Mikulicz of Breslau, he edited a handbook of practical surgery, of which the first edition appeared in 1900. He took an active part in the promotion of postgraduate study and was the founder and moving spirit of the Berlin ambulance organization. He was the recipient of many honours both in Germany, where he was given the title of Excellency and made a member of the Prussian House of Lords, and in other countries including England, where he was elected in 1900 an honorary fellow of the Royal College of Surgeons. He died at the age of seventy years on March 25, 1907, and was succeeded in the chair of surgery at Berlin by Prof. August Bier, who celebrated his seventy-fifth birthday on Novem. ber 24 .

\section{Alexander Neckham (II57-1227)}

IN his Friday evening discourse at the Royal Institution on December 4, Sir Stephen Gaselee discussed "Natural Science in England at the End of the Twelfth Century". It was impossible to survey all the English writers who were treating of natural science about A.D. 1200, but there is fortunately one who was widely read and a good compiler, and at the same time a personal observer of Nature-Alexander Neckham, born in 1157. He was born at St. Albans; afterwards he was headmaster of a school at Dunstable, and also studied in Paris. $\mathrm{He}$ later joined the Augustinian Canons at Cirencester, where he spent the rest of his life, becoming their abbot in due course, and died about 1227. He was an author of many and various works : one is called "Of the Natures of Things", and is partly a compilation from Pliny, Solinus and Cassiodorus ; but is not without evidence of his own personal investigations. There is continuous moralizing throughout the book; but in natural science he begins with a description of the firmament, the sun, moon and stars; then the four elements; and then starts a survey of the animal world, beginning with 